\title{
The effect of gelatin hydrolysate from pygostyle of broiler produced by enzymatic hydrolysis process of Aspergillus niger to prophylaxis
}

\author{
YASMI PURNAMASARI KUNTANA ${ }^{1}$, ROOSTITA BALIA ${ }^{2}$, SAYUTI MURAD ${ }^{1}$, YULI ASTUTI HIDAYAT ${ }^{2}$, \\ RUHYAT PARTASASMITA ${ }^{1, \vartheta}$ \\ ${ }^{1}$ Department of Biology, Faculty of Mathematics and Natural Sciences, Universitas Padjadjaran. J1. Ir. Soekarno Km. 21 Jatinangor, Sumedang 45363, \\ West Java, Indonesia. Tel.: +62-22-7796412, Fax.: +62-22-7796412, ”email: ruhyat.partasasmita@unpad.ac.id \\ ${ }^{2}$ Department of Animal Production Technology, Faculty of Animal Husbandry, Universitas Padjadjaran. Jl. Ir. Soekarno Km. 21 Jatinangor, Sumedang \\ 45363, West Java, Indonesia
}

Manuscript received: 28 May 2017. Revision accepted: 11 November 2017.

\begin{abstract}
Kuntana YP, Balia R, Murad S, Hidayat YA, Partasasmita R. 2017. The effect of gelatin hydrolysate from pygostyle of broiler produced by enzymatic hydrolysis process of Aspergillus niger to prophylaxis of osteoporosis white rat. Nusantara Bioscience 9: 361366. The pygostyle of the broiler is a cartilage tissue containing collagen, a mucoprotein being a plasma expander. The hydrolysis process of collagen by enzyme can produce gelatin hydrolysate differently compared to that from commercial gelatin because it has an amino acid composition with low average molecular weight. It becomes an advantage because it can be directly absorbed by the digestive tract. In addition, the enzymatic process can be done in short time with the low cost and also environment-friendly approach. This process can be assisted by Aspergillus niger, i.e., safe microorganisms (GRASS). A. niger has a protease enzyme that can digest collagen into gelatin hydrolysate. The enzyme is extracellularly removed so that its utilization does not require high input value expenditure. Gelatin hydrolysate can reduce the disease of osteoporosis. The objective of this study was to know the effect of gelatin hydrolysate produced from chicken bones in the favor of A. niger for increasing the benefit products. The specific targets are to find the amount of gelatin hydrolysate, precisely eliminated osteoporosis of rat (Rattus norvegicus). The experimental research was conducted in the laboratory with using complete randomized design followed by the descriptive analysis with 5 treatment and 5 replication. $\mathrm{CCl}_{4}$ dose $0,14 \mathrm{~mL} / \mathrm{g}$ BW (P1 as a negative control), Potatoes dextrose Broth (PDB) dose $0,5 \mathrm{~mL} / \mathrm{g} \mathrm{BW}$ (P2 positive control), gelatin hydrolysate dose $0.25 ; 0.5 ; 0.75 \mathrm{~mL} / \mathrm{g}$ BW (P3-P5). The observed parameters were including body weight and histological observation of musculoskeletal tissue in terms of measurement of fiber muscle, cartilage and collagen diameter. The test animal used was male white rat (R. norvegicus) Wistar strain aged 2-3 months with body weight 185-200 g. Data were analyzed using ANOVA and Duncan test. The results show that gelatin hydrolyzate as an environmentally friendly product serves as a prevention of immune diseases and degenerative diseases such as osteoporosis.
\end{abstract}

Keywords: Gelatin hydrolysate, osteoporosis, pygostyle

\section{INTRODUCTION}

Pygostyle is composed of cells and extracellular matrix. This extracellular matrix contains collagen fibers $( \pm 70 \%)$ and proteoglycans $( \pm 25 \%)$, which are also known as plasma expander. The tailbone is an area of the remaining primitive streak formed in the early embryogenesis phase during the process of gastrulation. This area induces formation of the definitive tissues such as neural tissue, epithelium, and somite, and that tail bone called a stem cell. Stem cells in the pygostyle have properties and features similar to fibroblasts as the collagen producer. The extracted collagen could be further used to produce the gelatin. In Indonesia, thousands of tons of gelatin has been imported per year to cope a high demand of gelatin in the domestic market, which the price was now ranging from Rp 60,000 to Rp 70,000 per kilogram (Robertis et al. 2009; Muttaqien et al. 2013; Asserin et al. 2015).

The process of extraction of tailbone is generally by acidic or alkaline ways. However, this process can cause the degradation of protein especially the essential amino acid. In addition, this process is not efficient because it takes a long time and less environment-friendly. The extraction of bone to form gelatin using enzymatic hydrolysis will produce gelatin hydrolysate, with a low weight of an amino acid, which could be directly absorbed by the digestive tract. This process occurs only by cutting the polypeptide on the aspartic acid site in favor of protease enzymes in order to inhibit the protein degradation. Gelatin hydrolysate does not produce an allergenic reaction and the processing technology does not require the release of high input values (Oesser et al. 1999; Schrieber and Gareis 2007; Gimenez et al. 2009).

One of the protease enzymes produced by organisms and classified as safe organism (GRASS) is Aspergillus niger. Fungi is widespread and can be easily mutated for increasing its productivity. In addition, it grows very quickly without removing mycotoxins. A. niger secretes protease enzymes extracellularly in the presence of substrate containing carbon and nitrogen sources such as collagen. These fungi can grow in keratin substrate because it has acid proteases. Based on this A. niger can convert collagen bone tissue to collagen gelatin (Chutmanop et al. 2008; Mukhtar and Ul-Haq 2009; Lopes et al. 2011). 
Several studies have shown that gelatin hydrolyzate has potential in the treatment of osteoporosis. Osteoporosis is a condition in which the substance, density, and bone mass have degenerated leading to the porous structure of bones. Osteoporosis can cause the reduction of bone capacity, which reduces its main function as support system so that bones become inelastic and fragile. Osteoporosis is an autoimmune chronic disease. Up to now, the etiology and pathogenesis of its main cause have not been fully understood. However, the exposure of foreign agents such as carbon tetrachloride compound $\left(\mathrm{CCl}_{4}\right)$, free radicals as well as changes in cellular homeostasis play an important role to trigger this disease (Schrieber and Gareis 2007).

Bone tissue is constantly undergoing remodeling process dynamically leading to imbalances of bone metabolism. The imbalance of bone tissue triggers the process of osteoporosis. The balance of bone metabolism is closely regulated by two body systems namely the endocrine system and the immune system. The presence of interference or damage to these two systems will cause interference and even damage to the musculoskeletal network. The presence of reactive oxygen species (ROS) has an important function in the pathophysiological changes of these tissues. Cell membranes are highly susceptible to the effects of ROS. The peroxidation of unsaturated fatty acids in the cell membrane will lead to decreased fluidity, loss of function, integrity disturbance and eventual cell death (Campo et al. 2004, 2008; Hsu et al. 2010; Xiao et al. 2012; Hadavi et al. 2015).

The essential amino acids contents of the hydrolyzate gelatin are glycine, proline, and hydroxyproline in addition to the semi-essential amino acids such as arginine and glutamic acid. Glycine and proline play a role in the formation of collagen, in addition to the components of hemoglobin and DNA, while hydroxyproline stimulates cellular metabolism. Arginine is needed in the subsequent creatine synthesis, this metabolite in phosphate form, plays a role in energy metabolism of muscle cells, increases insulin production, and increases growth hormone secretion. Glutamate acids improve cell regeneration process. Therefore, osteoporosis patients need to be rescued with the help of amino acids in the form of gelatin hydrolyzate (Xing et al. 2006; Maganhin et al. 2007; Schrieber and Gareis 2007; Campo et al. 2008). The objective of study is to obtain the amount of gelatin hydrolysate, precisely eliminated osteoporosis of rat (Rattus norvegicus)

\section{MATERIALS AND METHODS}

\section{Materials research}

The materials used include $2 \mathrm{~kg}$ Broiler bone, Fungi (A. niger) isolate, Medium Potatoes Dextrose Agar (PDA), Potatoes Dextrose Broth medium (PDB), Chloramphenicol, skimmed milk powder, Whatman No. 1 filter, aquadest, olive oil, carbon tetrachloride $\left(\mathrm{CCl}_{4}\right)$, Hematoxylin-Eosin dyes, formic acid, xylol, paraffin, alcohol, methanol, sterile gauze, cotton, gelatin hydrolysate and white rat (Rattus norvegicus) male Wistar strain.
The tools used include incubator (Incuterm Trade Raypa), hot plate, incubator shaker, laminar air flow, autoclave, staining jar, sonde, microtome rotate microme HM 310 brand, binocular light microscope brand Olympus $\mathrm{CH} 20$, ocular micrometer, fluorescence microscope (Axio), refrigerators, glassware, magnetic stirrer, and ose.

\section{Research methods}

The research was conducted Completely Randomized Design followed by descriptive analysis. White rat $(R$. norvegicus) males aged 2-3 months and body weight 180 $200 \mathrm{~g}$ amounted to 25 tails was used as test animals. Data were then analyzed with ANOVA followed by Duncan test. The observed variables include body weight, femoral muscle fiber diameter, cartilage diameter and femoral collagen diameter of a male white rat ( $R$. norvegicus) of Wistar strain.

The dose of gelatin hydrolysate administered to male rats ( $R$. norvegicus) was $10 \mathrm{mg} / \mathrm{g}$ human (Oesser et al. 1999), which was converted in rats to $0.2 \mathrm{mg} / \mathrm{g}$ BB rat. Dosing was developed into 3 doses of $0.25 ; 0.5$ and 0.75 $\mathrm{mL} / \mathrm{g} \mathrm{BW}$ rat. The dose of $\mathrm{CCl}_{4}$ given to mice was $1 \mathrm{~mL} / \mathrm{kg}$ $\mathrm{BW}$ mice as a hepatotoxic and pangcreatoxic dose (Campo et al. 2008). This dose was converted in rats to $0.14 \mathrm{~mL} / \mathrm{g} \mathrm{BW}$.

Rats were randomly assigned to 5 treatment groups with 5 replications: P1: negative control $\left(\mathrm{CCl}_{4}\right.$ dose 0,08 $\mathrm{mL} / \mathrm{g} \mathrm{BW}$ ); P2: Positive Control (PDB dose $0.5 \mathrm{~mL} / \mathrm{g}$ BW); P3: Gelatin Hydrolysate dose $0.25 \mathrm{~mL} / \mathrm{g} \mathrm{BW}$; P4: Gelatin Hydrolysate dose $0.5 \mathrm{~mL} / \mathrm{g}$ BW, and P5: Gelatin Hydrolysate dose $0.75 \mathrm{~mL} / \mathrm{g} \mathrm{BW}$.

Gelatin hydrolysate is administered orally daily using sonde for 14 days. After a day's rest, $\mathrm{CCl}_{4}$ treatment was administered daily for 7 days by intramuscular injection in the dorsal musculus of the rat femoral. The day after the $\mathrm{CCl}_{4}$ treatment was administered, the rats were weighed and killed and collected dorsal femoral muscle tissue and femur bone. The tissue samples were stored in a Bouin fixative solution for \pm 24 hours for the preparation of paraffin histologist preparations.

\section{RESULTS AND DISCUSSION}

\section{Body weight}

Based on body weight parameter, results showed that the treatment of gelatin hydrolysate doses gave a significant effect on body weight on $\alpha 0.05$ (Table 1).

Based on Duncan test result showed that treatment of gelatin hidrolisat dose $0,25 \mathrm{~mL} / \mathrm{g}$ BW (P3) gave different weight compared to treatment of P4 and P5 (dose of hydrolyzate 0,$5 ; 0,75 \mathrm{~mL} / \mathrm{g}$ ). Body weight of the result of treatment P3 was approaching the treatment of P2 as a positive control. Treatment P2 (PDB dose $0.5 \mathrm{~mL} / \mathrm{g} \mathrm{BW}$ ) gave the body weight significantly higher than the other treatment, while the treatment of $\mathrm{P} 1\left(\mathrm{CCl}_{4}\right.$ dose $0.14 \mathrm{~mL} / \mathrm{g}$ $\mathrm{BW}$ ) gaves the lowest weight significantly lower than the result of other treatments. Weight loss in mice due to $\mathrm{CCl}_{4}$ treatment was due to muscle tissue damage and reduced muscle mass. The presence of oxidative stress induced by $\mathrm{CCl}_{4}$ produces the $\mathrm{CCl}_{3}$ chemical compound that activates inflammation and cell death causing muscle atrophy (Munoz-Casares et al. 2006). 
Table 1. Average of body weight Rat ( $R$. norvegicus) male given gelatin hydrolysate and exposure on $\mathrm{CCl}_{4}$

\begin{tabular}{ll}
\hline Treatments & Average (g)* \\
\hline P1 (Negative control CC14 dose $0.14 \mathrm{~mL} / \mathrm{g} \mathrm{BW})$ & $199.07 \pm 0.042 \mathrm{e}$ \\
P2 (Positive control PDB $0.5 \mathrm{~mL} / \mathrm{g} \mathrm{BW})$ & $208.91 \pm 0.104 \mathrm{a}$ \\
P3 (Gelatin Hydrolysate dose $0.25 \mathrm{~mL} / \mathrm{g} \mathrm{BW})$ & $207.84 \pm 0.142 \mathrm{~b}$ \\
P4 (Gelatin Hydrolysate dose $0.5 \mathrm{~mL} / \mathrm{g} \mathrm{BW})$ & $205.79 \pm 0.082 \mathrm{c}$ \\
P5 (Gelatin Hydrolysate dose $0.75 \mathrm{~mL} / \mathrm{g} \mathrm{BW})$ & $202.64 \pm 0.043 \mathrm{~d}$ \\
\hline
\end{tabular}

Note: $*=$ significance 0.05

Provision of gelatin hydrolyzate can prevent tissue oxidative damage. This is evidenced by the study of Campo, et al. (2008) collagen from cattle bone dose 30 $\mathrm{mg} / \mathrm{kg} \mathrm{BB}$ mice that can reduce free radical production, prevent protein degeneration and inhibit cell damage. Collagen as an antioxidant may inhibit cell apoptosis (Rolls et al. 2005) According to Koopman et al. (2009), giving 35 $\mathrm{g}$ of casein in healthy adults does not show a decrease in skeletal protein synthesis. The amino acid digestion process will stimulate protein synthesis Muscles and inhibits protein damage so that the body's protein balance and improved functional functions are maintained (PaddonJones and Rasmussen 2009). Colomaterials such as collagen have low immunogenicity and perfect resorption power Collagen serves to transport bioactive substances in damaged tissues and release them in a controlled manner Hydrogel mechanical strength is able to accelerate tissue formation and provides necessary mechanical integrity (Elisseeff et al. 2005).

The provision of gelatin hydrolysate in osteoporotic patients decreases the loss of collagen and bone mass lower than that of calcium. The administration of gelatin hydrolysate in osteoarthritis patients also reduced pain by $50 \%$ and increased mobility compared with placebo (Moskowitz 2000; Schrieber and Gareis 2007). This affects the body weight. The body weight of mice who were given gelatin hydrolysate is greater than mice given $\mathrm{CCl}_{4}$.

The results showed that the decrease in body weight of mice continues to occur along with the increased dose of gelatin hydrolysate given. This is because gelatin hydrolysate inhibits tissue damage by stimulating the growth of new cells in damaged tissues without causing fatty. According to Asserin et al. (2015) collagen supports muscle elasticity and regeneration. The body weight of the treated rat $\mathrm{P} 2$ results in the highest value because the PDB solution is a nutrient-rich medium that triggers weight gain and fatty growth.

\section{Diameter file fiber muscle femoris}

The results of the observations on all treatments under the light microscope can be seen in Figure 1.

Based on the microscope observation, the P1 treatment (negative control, $\mathrm{CCl}_{4}$ dose $0.14 \mathrm{~mL} / \mathrm{g} \mathrm{BW}$ ) showed a non-uniform diameter of the muscle bundle, the presence of a muscle fiber lysis indicated by the empty space between the muscle bundles. The connective tissue undergoes fibrosis demonstrated by intermittent endomysium and permit membranes. Treatment P2 (positive control, PDB dose $0.5 \mathrm{~mL} / \mathrm{g} \mathrm{BW}$ ) did not show muscle tissue damage. It was characterized by an orderly arrangement of muscular bundles, uniform muscle bundle diameter, no lysis muscle fibers exhibited with tight muscle bands.

Treatment of P3 (gelatin hydrolysate dose $0.25 \mathrm{~mL} / \mathrm{g}$ BW) showed a similar picture with the result of treatment of $\mathrm{P} 1$ in spite of change, which leads to improvement. The space between the muscle fiber was wider than P2 but the connective tissue was more intact than the P1 treatment. The treatment of P4 (gelatin hydrolyzate at a dose of 0.5 $\mathrm{mL} / \mathrm{g} \mathrm{BW}$ ) showed the space between the tightly muscled bundles, the connective tissue intact although the lysis in the muscle fibers still happened. Treatment of P5 (gelatin hydrolysate dose $0.75 \mathrm{~mL} / \mathrm{g} \mathrm{BW}$ ) showed an intact connective tissue, uniform muscle bundle diameter, the tight space of muscle fiber and the regular arrangement of muscle bundles.

The result of ANOVA test showed that treatment was very different at $1 \%$ level. Table 2 is a table of Duncan test results in the diameter of femoral rat muscle fibers $(R$. norvegicus) of males between treatments.

Duncan test results showed that P4 treatment (gelatin hydrolysate dose $0.5 \mathrm{~mL} / \mathrm{g} \mathrm{BW}$ ) was not significantly different from the treatment of P2 (positive control) and treatment of P5 (gelatin hydrolysate dose $0.75 \mathrm{~mL} / \mathrm{g} \mathrm{BW}$ ) even though treatment of P5 was significantly different compared to treatment P2. Treatment of P3 (gelatin hydrolysate dose $0.25 \mathrm{~mL} / \mathrm{g} \mathrm{BW}$ ) and treatment of P1 $\left(\mathrm{CCl}_{4}\right.$ dose $\left.0.14 \mathrm{~mL} / \mathrm{g} \mathrm{BW}\right)$ was significantly different compared to other treatments. The treatment of P1 yielded the least significant different of all treatment values.

In this study, the damage of muscle tissue decreased with the increase dosage of gelatin hydrolyzate. This suggests that gelatin hydrolyzate can prevent muscle tissue damage due to $\mathrm{CCl} 4$ exposure. This in accordance with condition that skeletal muscle contains myoglobin, a protein that is very sensitive to free radicals. Skeletal muscle is highly susceptible to oxidative stress attacks due to oxidation processes that occur during contractions. Oxidative stress produces chemical compounds that trigger inflammation and cause damage to cell death (necrosis). These conditions can be inhibited by antioxidants. Antioxidants provide a biological response to a cellular melding of oxidative damage (Campo et al. 2004; MunozCasares et al. 2006).

Table 2. Diameter of femoris rat muscle ( $R$. norvegicus) male given gelatin hydrolysate and exposure on $\mathrm{CCl}_{4}$

\begin{tabular}{ll}
\hline Treatments & Average $(\mathbf{m m}) *$ \\
\hline P1 (Negative control CCl4 dose $0.14 \mathrm{~mL} / \mathrm{g} \mathrm{BW})$ & $16.20 \pm 1.64 \mathrm{~d}$ \\
P2 (Positive control PDB $0.5 \mathrm{~mL} / \mathrm{g} \mathrm{BW})$ & $31.80 \pm 2.39 \mathrm{a}$ \\
P3 (Gelatin Hydrolysate dose $0.25 \mathrm{~mL} / \mathrm{g} \mathrm{BW})$ & $22.40 \pm 3.36 \mathrm{c}$ \\
P4 (Gelatin Hydrolysate dose $0.5 \mathrm{~mL} / \mathrm{g} \mathrm{BW})$ & $29.60 \pm 2.30 \mathrm{ab}$ \\
P5 (Gelatin Hydrolysate dose $0.75 \mathrm{~mL} / \mathrm{g} \mathrm{BW})$ & $26.40 \pm 2.30 \mathrm{~b}$ \\
\hline Note: $*$ = significance 0.05 &
\end{tabular}




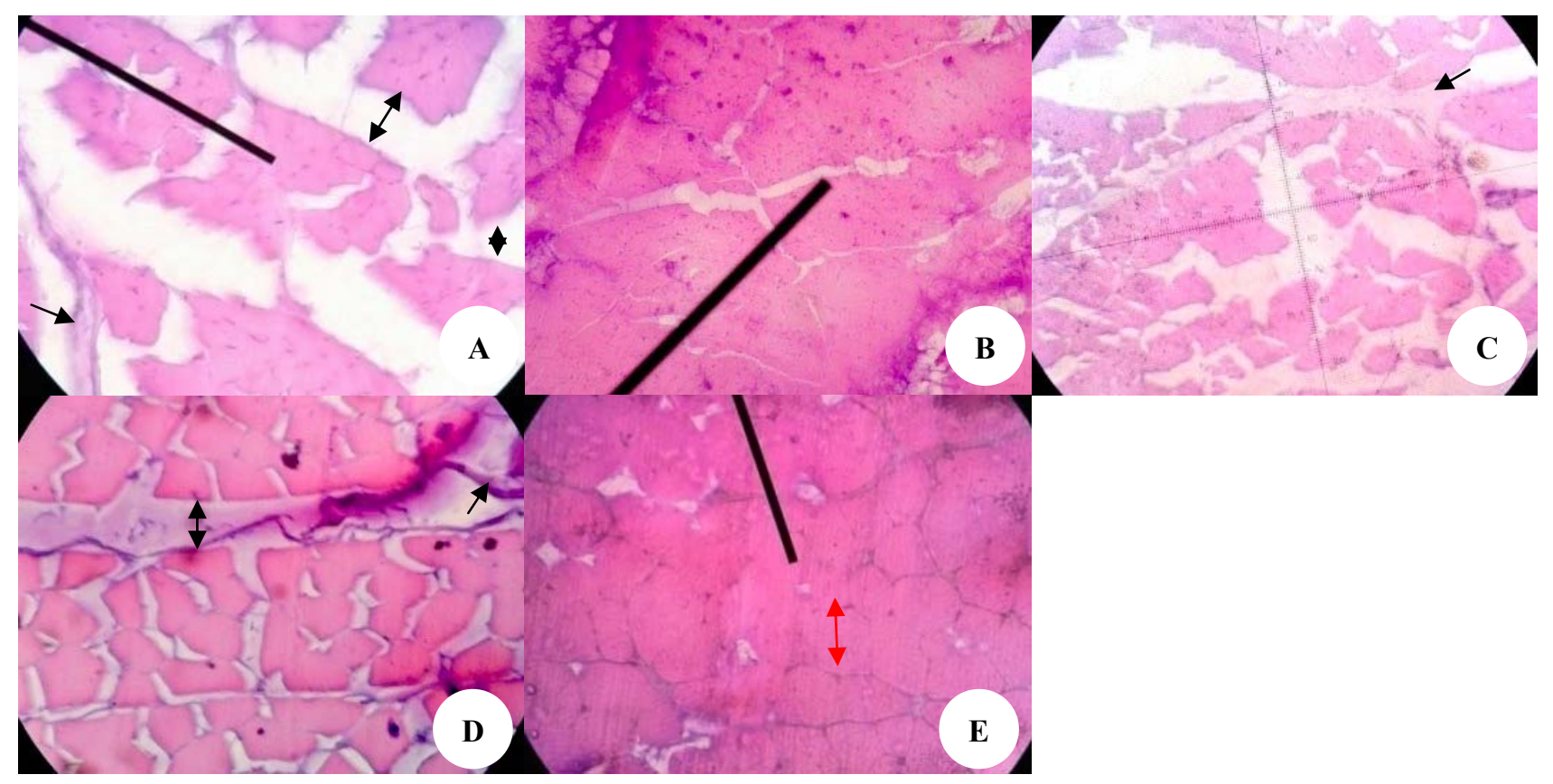

Figure 1. Cross section of Femoris Muscle Mice (R. norvegicus) Male is Given Gelatin Hydrolysate and Exposure to CCl 4 . Note: A. P1 (Negative control $\mathrm{CCl}_{4}$ dose $0.14 \mathrm{~mL} / \mathrm{g} \mathrm{BW}$ ); B. P2 (Positive control PDB 0.5mL/g BW); C. P3 (Gelatin Hydrolysate dose $0.25 \mathrm{~mL} / \mathrm{g}$ BW); D. P4 (Gelatin Hydrolysate dose $0.5 \mathrm{~mL} / \mathrm{g}$ BW); E. P5 (Gelatin Hydrolysate dose $0.75 \mathrm{~mL} / \mathrm{g} \mathrm{BW}$ ), Light microscope, Hematoxylin Eosin staining, magnification 100X, $\leftrightarrow$ : empty space, $>$ : perimisium, $\leftrightarrow$ : the diameter of the muscle bundle

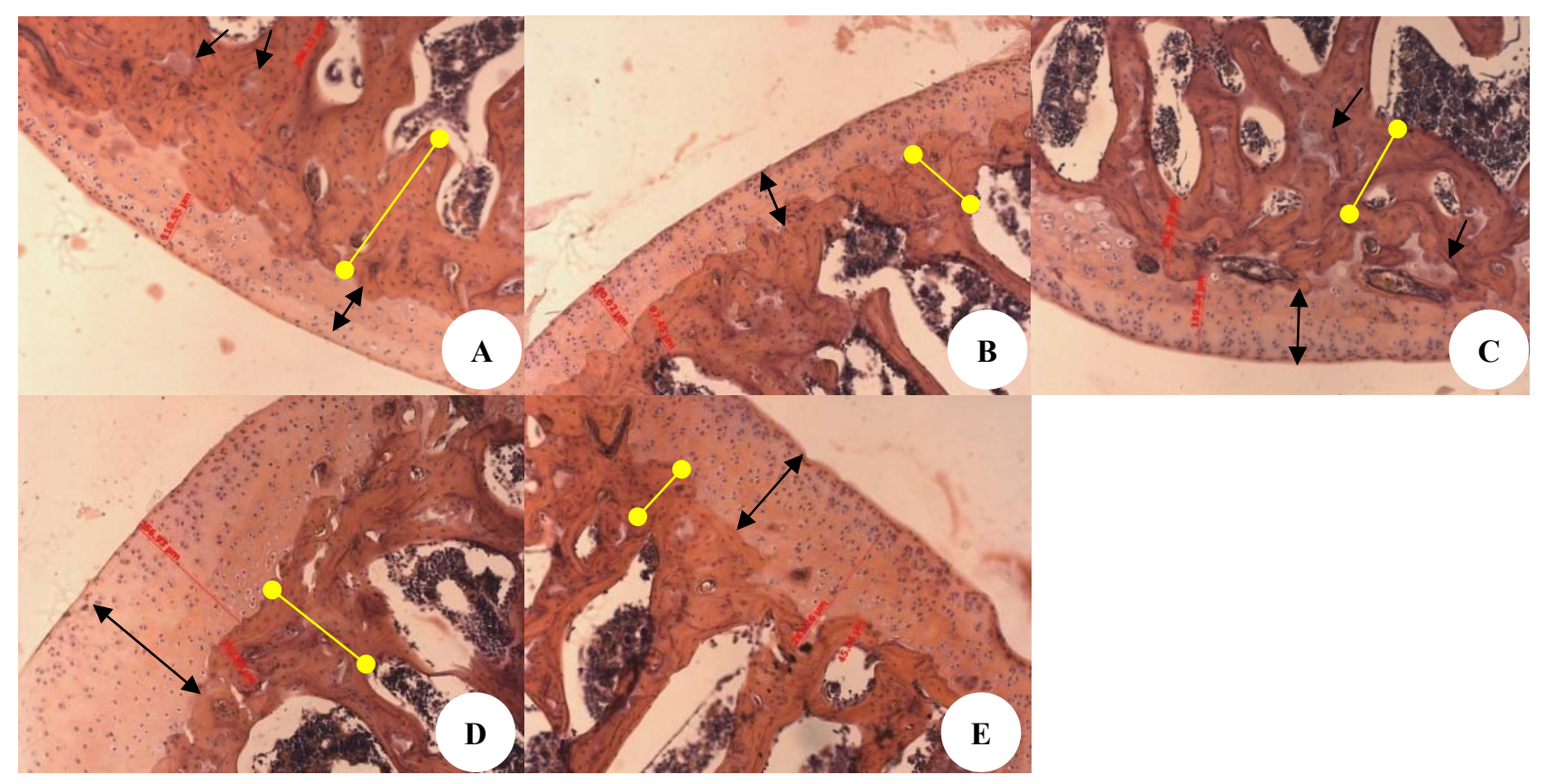

Figure 2. Cross section of tissue femur bone of rat (R. norvegicus) male are given gelatin hydrolysate and exposure to $\mathrm{CCl}_{4}$. Note: A. $\mathrm{P} 1$ (negative control CCl4 dose $0.14 \mathrm{~mL} / \mathrm{g} \mathrm{BW}$ ); B. P2 (Positive control PDB dose $0.5 \mathrm{~mL} / \mathrm{g} \mathrm{BW}$ ); C. P3 (Gelatin Hydrolysate dose 0.25 $\mathrm{mL} / \mathrm{g} \mathrm{BW}$ ); D. P4 (Gelatin Hydrolysate dose $0.5 \mathrm{~mL} / \mathrm{g} \mathrm{BW}$ ); E. P5 (Gelatin Hydrolysate dose $0.75 \mathrm{~mL} / \mathrm{g} \mathrm{BW}$ ). Fluorescence Microscope, Hematoxylin-Eosin staining, Magnification 100X, Red line indicates the size of the cartilage and collagen diameter, $\leftrightarrow$ : cartilage diameter, $P$ : collagen diameter, $\boldsymbol{\alpha}$ : adipose cells 
The provision of gelatin hydrolyzate is more efficient than synthetic antioxidants because it does not cause apoptosis and cellular necrosis. According to Schrieber and Gareis (2007) collagen dose 10, g/kg human BB per day is safe for consumption in a long term $( \pm 3$ months $)$. The dosage of gelatin hydrolyzate administered in this study was not less than the human safe dose. Consumption of gelatin hydrolyzate regularly increases muscle protein synthesis and responds to major anabolic stimuli of food and better physical activity (Koopman and Van Loon 2009).

\section{Susceptible diameter and collagen}

The observations on all treatments under the fluorescence microscope can be seen in Figure 2.

Based on the microscope observation, treatment P1 (negative control, $\mathrm{CCl} 4$ dose $0.14 \mathrm{~mL} / \mathrm{g} \mathrm{BW}$ ) showed the decreased cell size (chondrocyte) and the proliferation process either aposition or interstitial in the epiphyseal region, bone cells (osteocytes) in rare trabeculae visible, which could be seen from the amount of free space. The connective tissue (collagen) dilates as do the blood vessels in it. Adipose cells are also found in it. These conditions indicate the presence of inflammation (inflammation) as well as abnormal fatty. Treatment P2 (positive control, PDB dose $0.5 \mathrm{~mL} / \mathrm{g} \mathrm{BW}$ ) showed the presence of appetent cell growth and bone cells in trabeculae. The enlargement of connective tissue (collagen) and blood vessels also occured. Treatment of P3 (gelatin hydrolysate dose 0.25 $\mathrm{mL} / \mathrm{g} \mathrm{BW}$ ) showed a better aposition proliferation of cells as well as the proliferation of bone cells. Connective tissue (collagen) and blood vessels are thinner than Treatments P1 and P2. No abnormal adipose cell growth was found. Treatment of P4 (gelatin hydrolysate dose $0.5 \mathrm{~mL} / \mathrm{g} \mathrm{BW}$ ) showed the best histologist picture compared with Treatment of P3 and P5. The process of cell proliferation was prone to aposition while bone cells, connective tissue (collagen) and blood vessels was apparently in normal condition. Treatment of P5 (gelatin hydrolysate dose 0.75 $\mathrm{mL} / \mathrm{g} \mathrm{BW}$ ) showed the presence of a proliferation of cartilage cells and bone cells. The connective tissue (collagen) and blood vessels look normal. No abnormal adipose cell growth was found. Based on the description, it is shown that administration of gelatin hydrolyzate in mice can resist the rate of cell necrosis due to $\mathrm{CCl} 4$ exposure.

ANOVA test results in prone diameter indicate that the treatment was different at the level of 0.05 . Table 3 below is a table of Duncan test results of prone diameter on rat femur ( $R$. norvegicus) between males treated.

Table 3. Test result of duncan test of rat assistive diameter $(R$. norvegicus) male given gelatin hydrolysate and exposure on $\mathrm{CCl}_{4}$

\begin{tabular}{ll}
\hline Treatments & Average $(\mathbf{m m})^{*}$ \\
\hline P1 (Negative control CCl4 dose $0.14 \mathrm{~mL} / \mathrm{g} \mathrm{BW})$ & $201.88 \pm 57.42^{\mathrm{b}}$ \\
P2 (Positive control PDB $0.5 \mathrm{~mL} / \mathrm{g} \mathrm{BW})$ & $141.61 \pm 34.36^{\mathrm{b}}$ \\
P3 (Gelatin Hydrolysate dose $0.25 \mathrm{~mL} / \mathrm{g} \mathrm{BW})$ & $169.09 \pm 21.45^{\mathrm{b}}$ \\
P4 (Gelatin Hydrolysate dose $0.5 \mathrm{~mL} / \mathrm{g} \mathrm{BW})$ & $285.05 \pm 59.42^{\mathrm{a}}$ \\
P5 (Gelatin Hydrolysate dose $0.75 \mathrm{~mL} / \mathrm{g} \mathrm{BW})$ & $197.60 \pm 51.61^{\mathrm{b}}$ \\
\hline
\end{tabular}
Note: ${ }^{*}=$ significance 0.05
Duncan test results showed that all treatment was not significantly different. The administration of $\mathrm{CCl}_{4}$ induces a cellular inflammatory response that causes progressive damage to the extracellular matrix (ECM) and cells. This can be seen from the large diameter of collagen and blood vessels in the femur bones of mice given $\mathrm{CCl}_{4}$. Exposure to $\mathrm{CCl}_{4}$ also promotes cell apoptosis leading to necrotic tissue damage (Campo et al. 2008).

Gelatin hydrolysate stimulates collagen synthesis. Oesser et al. (1999) showed $\pm 10-15 \%$ gelatin hydrolysate can pass through the intestinal wall and reach the bloodstream until it finally accumulates in the cartilage. Gelatin hydrolysate stimulates collagen biosynthesis in chondrocytes (cartilage cells). The presence of gelatin hydrolysate causes an increase in type II collagen. Collagen type II is a cartilage network (Schrieber and Gareis 2007). Observations under the microscope showed an increase in the proliferation of susceptible cells in mice treated with gelatin hydrolysate.

Based on this, the tail bone has prospectively to be developed because it still has stem cells that can prevent damage to rat musculoskeletal tissue ( $R$. norvegicus). This suggests that gelatin hydrolysate is an environmentally friendly product that serves as a preventative of immunodeficiency and degenerative diseases such as osteoporosis

\section{ACKNOWLEDGEMENTS}

Acknowledgments are given to the Research and Testing Laboratory of the Faculty of Animal Husbandry of Padjadjaran University, Test Laboratory of Faculty of Agricultural Technology of Padjadjaran University, Physical Chemistry Laboratory of Chemistry Faculty of Mathematics and Natural Sciences, Padjadjaran University and Laboratory of Animal Structure and Development, Department of Biology, Faculty of Mathematics and Natural Sciences, Padjadjaran University, Sumedang, Indonesia.

\section{REFERENCES}

Asserin J, Lati E, Shioya T, Prawitt J. 2015. The Effect of Oral Collagen Peptide Supplementation on Skin Moisture and The Dermal Collagen Network: Evidence from An Ex Vivo Model and Randomized, Placebo-Controlled Clinical Trials. Cosmetic Dermatol 14: 291-301

Caetano-Lopes J, Canhao H, Fonseca JE. 2009. Osteoimmunology-The Hidden Immune Regulation of Bone. Autoimmun Rev 8: 250-255.

Campo GM, Angela A, Salvatore C, Angela DA, Alida MF, Alberto C. 2004. The antioxidant and antifibrogenic effects of the glycosaminoglycans hyaluronic acid and chondroitin-4-sulphate in a subchronic rat model of carbon tetrachloride-induced liver fibrogenesis.Chemico-Biol Interact (148) 3: 125-138.

Campo GM, Angela A, Salvatore C, Alida MF, Domenica A, Alberto C. 2003. Efficacy of treatment with glycosaminoglycans on experimental collagen-induced arthritis in rats. Arthritis Res Ther 5 (3): 122-131.

Campo GM, Avenoso A, Campo S, Nastasi G, Traina P, D'Ascola A, Rugolo CA, Calatroni A. 2008. The antioxidant activity of chondroitin-4-sulphate, in carbon tetrachloride-induced acute hepatitis in mice, involves NF-jB and caspase activation. Pharmacology 155 : 945-956. 
Campo GM, Avenoso A, Campo S, Nastasi G, Traina P, D'Ascola A, Calatroni A. 2008. Chondroitin-4-sulphate reduced oxidative injury in caerulein-induced pancreatitis in mice: the involvement of NFkappaB translocation and apoptosis activation. Exp Biol Med 233 (6): 741-52.

Elisseeff JCP, Yang F, Sharma B. 2005. Advances in Skeletal Tissue Engineering with Hydrogels. Orthodont Craniofac Res 8: 150-161.

Gilbert SF. 2007. Developmental Biology, 7th ed. Sinauer, Sunderland, MA.

Gimenez B, Aleman A, Montero P, Gomez Guillen MC. 2009. Antioxidant and functional properties of gelatin hydrolysates obtained from the skin of sole and squid. Food Chem 114 (3): 976-983

Hadavi A, Kermanshahi H, Nassiri Moghaddam H, Golian A. 2015. Performance and Serum Hepatic Enzymes of Hy-line W-36 Laying Hens Intoxicated with Dietary Carbon Tetrachloride. Poultry Sci 3 (2): $159-164$

Koopman R, Van Loon LJ. 2009. Aging, exercise and muscle protein metabolism. Appl Physiol 106 (6): 2040-2048.

Koopman R, Walrand S, Beelen M, Gijsen AP, Kies AK, Boirie Y, Saris WH, Van Loon LJ. 2009. Dietary protein digestion and absorption rates and the subsequent postprandial muscle protein synthetic response do not differ between young men and elderly men. Nutrition 139 (9): 1707-1713.

Lopes FC, Silva LA, Tichota DM, Daroit DJ, Velho RV, Pereira JQ, Correa APF, Brandelli A. 2011. Production of proteolytic enzymes by a keratin-degrading Aspergillus niger. Enzyme Res 2011: 1-9. DOI: $10.4061 / 2011 / 487093$

Maganhin CC, Correa O, Gomez RCT, Simoes R, Baracat EC, Soares-Jr JM. 2007. Effects of glucosamine on the tibial epiphyseal disk of ovariectomized rats: morphologic and morphometric analysis. Clinics 62 (5): 607-612.

Monod M, Togni G, Rahalison L, Frenk E. 1991. Isolation and characterisation of an extracellular alkaline protease of Aspergillus fumigatus. Med Microbiol 35: 23-38.

Moskowitz RW. 2000. The role of Collagen Hydrolysate in Bone and Joint Disease. Seminar in Arthritis and Rheumatism 30 (2): 87-99

Mukhtar H, Ul-Haq I. 2009. Production of acid protease by Aspergillus niger using solid state fermentation. Pakistan Zool 41 (4): 253-260
Munoz-Casares FC, Padillo FJ, Briceno J, Collado JA, Munoz-Castaneda JR, Ortega R, Cruz A, Tunez I, Montilla P, Pera C, Muntane J. 2006. Melatonin reduces apoptosis and necrosis induced by ischemia/reperfusion injury of the pancreas. Pineal Res 40: 195-203.

Muttaqien AT, Nuhriawangsa AMP, Pudjomartatmo, Swastike W. 2013. Physical properties of edible films of gelatin shank broiler chickens and their effects on microbe meat breeding cats with different savings period. Trop Anim Husbandr 2 (1): 15-20.

Oesser S, Adam M, Babel W, Seifert J. 1999. Oral Administration of 14 C Labeled Gelatin Hydrolysate Leads to An Accumulation of Radioactivity in Cartilage of Mice (C57/BL). Nutr 129 (10): 18911895

Paddon-Jones D, Rasmussen BB. 2009. Dietary protein recommendations and the prevention of Sarcopenia. Curr Opin Clin Nutr Metab Care 12 (1): 86-90.

Pelczar MJJr, Chan ECS. 2012. Basics of Microbiology 2. Publisher University of Indonesia, Jakarta [Indonesia]

Robertis EMD. 2009. Spemann's organizer and the self-regulation of embryonic fields. Mech Dev 126: 925-941.

Rolls ALC, Bakalash S, Avidan H, Lider O, Schwartz MA. 2005. Sulphated disaccharide derived from chondroitin sulphate proteoglycan protects against inflammation-associated neurodegeneration. The FASEB 3: 547-549.

Schrieber R, Gareis H. 2007. Gelatine Handbook Theory and Industrial Practice. Wiley-VCH Verlag Gmbh, Co. KGaA, Weinheim.

Sipos W, Pietschmann P, Rauner M, Schindl KK, Patsch J. 2009. Pathophysiology of osteoporosis. Wien Med Wochenschr 159: 230234.

Hsu YW, Tsai CF, Chuang WC, Chen WK, Ho YC, Lu FJ. 2010. Protective Effects of Silica Hydride Against Carbon TetrachlorideInduced Hepatotoxicity in Mice. Food Chem Toxicol 48: 1644-1653.

Xiao J, Liong EC, Ching YP, Chang RCC, So KF, Fung ML, Tipoe GL. 2012. Lycium barbarum polysaccharides protect mice liver from carbon tetrachloride-induced oxidative stress and necroinflammation. J Ethnopharmacol 139: 462-470.

Xing R, Liu S, Guo Z, Yu H, Li C, Ji X, Feng J, Li P. 2006. The antioxidant activity of glucosamine hydrochloride in vitro. J. Bioorg Med Chem 14 (6): 1706-1709. 